Clergy Discipline Rules 2005, SI 2005/2022, states that hearings are normally to be in private and that the public interest would satisfied by the requirement of rule 50 that the tribunal's determination be pronounced in public. The chairman also ruled that written evidence of the child of the complainant be admitted without the child being called under Rule 35(4) (c) of the Clergy Discipline Rules. In coming to this decision he had regard to the fact that most of this evidence was agreed by both sides and that the child had a medical condition that would make his appearance difficult. However, the tribunal's weighing of the evidence would take into account the inability of the complainant's solicitor to cross-examine the witness. In March 2008, the Chancery Court of York dismissed the appeal of the respondent against the penalty imposed by the Tribunal. [WA]

doi: 10.1017/So956618Xo800135X

\title{
Green v City of Westminster Magistrates' Court
}

Administrative Court: Hughes LJ, Collins J, December 2007 Blasphemous libel - freedom of religion - freedom of expression

G applied for a judicial review of the District Judge's decision to refuse to issue summonses for blasphemous libel against the producer of Jerry Springer: the opera and against the Director General of the BBC. In refusing the application, the Court set out the two elements of the offence of blasphemous libel, namely:

i. The need for contemptuous, reviling, scurrilous and/or ludicrous material relating to God, Christ, the Bible or the formularies of the Church of England; and

ii. The need for the publication to be such as tends to endanger society as a whole, by endangering the peace, depraving public morality, shaking the fabric of society or tending to cause civil strife.

The court observed obiter that a commission of the offence was unlikely to amount to a breach of a person's right to freedom of religion under Article 9 of the European Convention on Human Rights, as a person's right to practise his religion was generally unaffected by insults to that religious belief. Further, the court observed that the offence was compatible with the right to freedom of expression under Article 10 of the Convention as the basis for the offence was best found in the risk of disorder amongst, and damage to, the community generally. An appellate committee refused leave to appeal to the House of Lords in March 2008. [RA] 